\title{
ZBRODNIE HITLEROWSKIE NA POMORZU GDAŃSKIM W LATACH 1939-1940. PIAŚNICA: GENEZA, UWARUNKOWANIA, ZBRODNIA I PAMIEĆ́
}

\author{
Dariusz Ostapowicz \\ VI Liceum Ogólnokształcące im. Obrońców Helu w Gdańsku \\ The Defenders of Sea-Coast 1939 VI High School in Gdańsk \\ e-mail: ostapowicz@wp.pl
}

\begin{abstract}
Streszczenie. Masowe mordy w Piaśnicy dokonywane od jesieni 1939 do wiosny 1940 r. to jedne z największych zbrodni hitlerowskiego okupanta w północnej Polsce. Śmierć poniosło tam około dwanaście tysięcy przedstawicieli polskiej elity: przywódcy polityczni, działacze społeczni, inteligencja, duchowieństwo rzymskokatolickie. Eksterminacji podlegali również pacjenci szpitali psychiatrycznych. U podstaw tego ludobójstwa leżały: niemiecki rewanżyzm wobec postanowień traktatu wersalskiego, postulaty Lebensraumu i germanizacji oraz zbrodnicza ideologia nazizmu. Odpowiedzialność za zbrodnię - a także zaplanowane jeszcze przed wojną czystki etniczne, w tym deportacje Polaków do Generalnego Gubernatorstwa i obozu koncentracyjnego Stutthof - spoczywa na składających się z przedstawicieli niemieckiej mniejszości narodowej w II Rzeczypospolitej paramilitarnych bojówkach Selbstschutzu oraz podlegającym grupie operacyjnej SS Einsatzkommando 16 oddziale SS-Wachsturmbann „Eimann”. W trudnej sytuacji znaleźli się miejscowi Kaszubi, zagrożeni eksterminacją w razie odmowy przystosowania się. Piaśnica miała być w oczach hitlerowców wzorem dla kolejnych zbrodni, np. w Lesie Szpęgawskim. Obecnie, m.in. dzięki inicjatywie Stowarzyszenia „Rodzina Piaśnicka”, las, w którym dokonano zbrodni, jest miejscem pamięci narodowej z sanktuarium maryjnym.
\end{abstract}

Słowa kluczowe: Piaśnica, Selbstschutz, SS-Wachsturmbann „Eimann”, eksterminacja.

\section{GENEZA ZBRODNI}

Piaśnica to miejsce martyrologii kilkunastu tysięcy ofiar zbrodniczej działalności okupanta hitlerowskiego w czasie drugiej wojny światowej, zwłaszcza mieszkańców Pomorza Gdańskiego. Choć czasami nazywane jest pomorskim Katyniem lub Golgotą Kaszub, to w ogólnopolskiej świadomości historycznej - w przeciwieństwie do miejsc kaźni w Palmirach, Wawrze, Auschwitz, Stutthofie czy Majdanku pozostaje mało znane. Celem niniejszego artykułu jest ukazanie genezy i przebiegu zbrodni dokonanej przez Niemców w lasach piaśnickich w latach 1939-1940 na 
tle polityki ludobójstwa i czystek etnicznych na włączonym do III Rzeszy obszarze Pomorza Gdańskiego, tj. Okręgu Rzeszy Gdańsk-Prusy Zachodnie (Reichsgau Danzig-Westpreußen). Podstawowe i najważniejsze źródła dotyczące tej problematyki opublikowała w książce o Piaśnicy dr Anna Bojarska, a bibliografia literatury przedmiotu znajduje się np. w artykule Elżbiety Grot ${ }^{1}$.

Genezy masakry piaśnickiej należy szukać zarówno w dwudziestoleciu międzywojennym (zbrodniczej ideologii nazizmu, rewizjonistycznej polityce Adolfa Hitlera wobec postanowień traktatu wersalskiego i konfliktach terytorialnych między Niemcami i Polakami zamieszkującymi te tereny), jak i w bezpośredniej realizacji założeń hitlerowskiego Lebensraumu ('przestrzeni życiowej') w latach okupacji. U źródeł nienawiści Niemców do Polaków leżała decyzja konferencji pokojowej w Paryżu - przyznanie rodzącej się II Rzeczypospolitej Polskiej Pomorza Gdańskiego. Problemem była też postawa mniejszości niemieckiej wobec nowej rzeczywistości politycznej i polskich sąsiadów, obszary etniczne nie pokrywały się bowiem dokładnie z oczekiwanym zasięgiem granic odrodzonej Polski ${ }^{2}$. Postulaty przyznania państwu polskiemu dostępu do morza pojawiały się już pod koniec pierwszej wojny światowej. Zwłaszcza Roman Dmowski konsekwentnie lansował tezę wyrażoną w 1917 r. w Memoriale o terytorium państwa polskiego - o delimitacji obszaru Polski na północy i zachodzie wykraczającej poza linię z 1772 r. ${ }^{3}$ Aspiracje te zostały wsparte przez konkretne działania: powstanie wielkopolskie, utworzenie Polskich Rad Ludowych na Pomorzu oraz powołanej 30 grudnia 1918 r. Organizacji Wojskowej Pomorza, której działalność koncentrowała się na sprawach wywiadowczych i gromadzeniu ochotników do powstania wielkopolskiego, szkoleniu agitatorów oraz przekazywaniu delegatom polskim na konferencję pokojową w Paryżu materiałów świadczących o polskości Pomorza ${ }^{4}$. Wśród Niemców wywołało to poczucie zagrożenia - woleli oni pozostać w Rzeszy lub utworzyć separatystyczne państwo wschodnioniemieckie, obejmujące m.in. Pomorze Gdańskie i Prusy Wschodnie ${ }^{5}$. Wstępowali więc do Grenschutzu-Ost -

1 B. Bojarska, Piaśnica. Miejsce martyrologii i pamięci. Z badań nad zbrodniami hitlerowskimi na Pomorzu, Wejherowo-Gdańsk 2009; E. Grot, Zbrodnie hitlerowskie w Piaśnicy: stan badań i postulaty, „Acta Cassubiana”, 3(2001), s. 27-42.

2 R. WAPIŃSKI, Polska i mate ojczyzny Polaków. Z dziejów ksztaltowania się świadomości narodowej w XIX i XX wieku po wybuch II wojny światowej, Wrocław 1994, s. 239-240.

3 Tamże, s. 262-263, 267-268.

4 B. Chrzanowski, A. Gąsiorowski, K. Steyer, Polska podziemna na Pomorzu w latach 1939-1945, Gdańsk 2005, s. 17-19; J. BorzyszKowski, Gdańsk i Pomorze w XIX i XX wieku, Gdańsk 1999, s. 144-146; A. Drzycimski, Polacy w Wolnym Mieście Gdańsku w latach 1920-1933, Wrocław 1978, s. 50-51.

5 Tamże, s. 18 (projekt wydzielenia polskiego portu w niemieckim Gdańsku z 1917 r.), 81-82 (projekt wschodniopruski z 1919 r.). 
ochotniczej organizacji paramilitarnej tłumiącej próby powstańcze w Chmielnie, Świeciu, Toruniu, a zwłaszcza w Chełmży ${ }^{6}$. W gdańskiej prasie obiektywne informacje o przebiegu konferencji pokojowej w Paryżu (głównie pracach komisji Julesa Cambona) mieszały się z kłamstwami o polskim terrorze w Wielkopolsce oraz prognozami o fatalnych skutkach zmiany granic (bezrobociu i kryzysie w rolnictwie) $)^{7}$. Nie poprzestano jednak na anonsach prasowych. W Gdańsku odbyły się wiece i zebrania, na których kierowano do niemieckiego państwa żądanie obrony terytorialnego status quo. Sprzedaż ziemi w polskie ręce piętnowano jako zdradę i wieszczono ogólną repolonizację (Organizacja Wojskowa Pomorza przygotowała skorowidz polskich nazw miejscowości, a w 1920 r. usuwano niemieckie napisy i pomniki) ${ }^{8}$. Polacy obawiali się natomiast niemieckiego rewanżyzmu i przewagi gospodarczej zachodniego sąsiada9.

Specyfiką pomorską było dodatkowo zróżnicowanie etniczne i liczne animozje: niemiecko-polskie, gdańsko-polskie (docierające do Ligi Narodów) ${ }^{10}$ i kaszubsko-polskie oraz niesnaski między Kaszubami ${ }^{11}$, wykorzystywane w propagandzie Berlina i Warszawy. Niemiecka lansowała tezę o odrębności Kaszubów od Polaków, co jednak nie zapobiegło ich późniejszej eksterminacji i wysiedleniom ${ }^{12}$.

6 M. StaŻewski, Sprawa ,niebezpieczeństwa polskiego” na łamach niemieckiej prasy w Gdańsku w pierwszej połowie 1919 roku, w: Gdańsk i Pomorze w XX wieku, red. M. Andrzejewski, Gdańsk 1997, s. 116-119, przyp. 20, 29.

7 Wojna na Kaszubach. Pamięć polskich i niemieckich świadków, oprac. R. Borchers, K. Madoń-Mitzner, Gdańsk 2014, s. 70, 72.

8 M. StażEwsKi, Sprawa „niebezpieczeństwa polskiego”..., s. 120-121; D. MATELSKI, Niemcy i mniejszość niemiecka na Pomorzu Gdańskim (1920-1945), „Rocznik Gdański”, 58(1998), z. 1, s. 39. Na rewanżystowską propagandę Gustava Stresemanna Republika Weimarska przeznaczała $6 \mathrm{mln}$ marek rocznie (1926-1929), Wolne Miasto Gdańsk zostało przekupione za 4 mln marek dotacji. Zob. też recenzję książki The free city. Danzig and German foreign policy Christopha Kimmicha: W. ZAJEWski, Wolne Miasto Gdańsk, „Litery”, 9(1970), nr 6, s. 30-31.

9 R. WapiŃsKi, Świadomość polityczna w Drugiej Rzeczypospolitej, Łódź 1989, s. 271, 436-437.

${ }^{10}$ A. Drzycimski, Polacy w Wolnym Mieście Gdańsku..., s. 95-98. Autor poświęcił tę książkę antypolskiej polityce Senatu Wolnego Miasta Gdańska, m.in. po zwycięstwie wyborczym NSDAP: biciu Polaków, niszczeniu mienia, sklepów, skrzynek pocztowych i szykanom wobec uczniów i harcerzy. Tamże, s. 293-300.

${ }^{11}$ Skupione wokół czasopism „Gryf” i „Klëka” środowisko tzw. młodokaszubów podkreślało ważność kultury regionalnej tożsamej z polskością, podczas gdy „Zrzesz Kaszëbskô” uwypuklała kaszubską odrębność narodową, co spotkało się ze sprzeciwem na łamach „Klëki”. Zob. J. BorzYszKowsKi, Gdańsk i Pomorze..., s. 226-228; D. SzyмiкоwsKi, ,,Zrzesz Kaszëbskô” w latach 1933-1939, Bolszewo 2010, s. 88-89, 93-101. W kręgach „Zrzesz Kaszëbskô” krytykowano Polskę sanacyjną za fatalną politykę regionalną, a Gdańsk uważano za kaszubski, co w żadnej mierze nie przeszkadzało podkreślać więzi Pomorza z Polską. Władze widziały jednak w zrzeszeńcach proniemieckich separatystów.

${ }^{12}$ B. BreZA, Pomiędzy oporem a przystosowaniem. Kaszubi w Okręgu Rzeszy Gdańsk-Prusy Zachodnie 1939-1945, „Rocznik Gdański”, t. 64(2004), z. 1-2, s. 52, 57. 
W 1939 r. postawy Kaszubów wobec wojennej rzeczywistości okazały się różne: jedni bronili ojczyzny w szeregach Pomorskiej Brygady Obrony Narodowej, inni uciekali na wschód, a jeszcze inni witali Wehrmacht kwiatami i swastykami. Generalnie jednak, widząc zbrodnie i politykę antykatolicką, optowali za polskością, ale okupant zmuszał ich do podpisywania niemieckiej listy narodowościowej-volkslisty ${ }^{13}$. Tylko 6 proc. autochtonów podkreślało wyłącznie przynależność kaszubską, większość zaś mogła powtórzyć za czasopismem „Gryf” (1919): „My, Kaszubi, jesteśmy i zostaniemy na naszej polskiej ziemi Polakami”" ${ }^{14}$.

Mniejszość niemiecką na Pomorzu Gdańskim, liczącą w 1931 r. 175 tys. osób (9,8 proc.), tworzyli głównie rzemieślnicy, rolnicy oraz miejscy i wiejscy robotnicy, stanowiący łącznie 84,4 proc. tej społeczności ${ }^{15}$. Ich aktywność polityczna skupiała się m.in. wokół Partii Niemieckiej (Deutsche Partei) i Niemieckiego Zjednoczenia w Zachodniej Polsce (Deutsche Vereinigung in Westpolen), a pronazistowskie sympatie prezentowała tylko Partia Młodoniemiecka w Polsce (Jungdeutsche Partei in Polen $)^{16}$. W czasie drugiej wojny światowej wszystkie te ugrupowania zostały jednak rozwiązane przez władze III Rzeszy. Nie wszystkich niemieckich obywateli II RP można też nazywać piątą kolumną ${ }^{17}$. Wielu z nich wspierało np. Fundusz Obrony Narodowej, a w Piaśnicy poza Polakami ginęli m.in. niemieccy antynaziści, a także przywożeni z Niemiec pacjenci zakładów psychiatrycznych ${ }^{18}$. Inni jednak wstępowali do SS, SA czy Selbstschutzu, by jak radny Wejherowa Gustaw Bamberger wydawać Polaków na pewną śmierć ${ }^{19}$.

${ }^{13}$ Deutsche Volksliste dzieliła się na cztery kategorie: 1. osoby narodowości niemieckiej aktywne politycznie (Volksdeutscher); 2. osoby narodowości niemieckiej bierne politycznie, ale kultywujące tradycje (Deutschstämmige); 3. autochtoni uważani za częściowo spolonizowanych Niemców (Eingedeutschte); 4. spolonizowane osoby niemieckiego pochodzenia, wcześniej aktywne politycznie w polskich organizacjach, oraz Polacy uznani za wartościowych rasowo (Rückgedeutschte). Do 1944 r. w Okręgu Gdańsk-Prusy Zachodnie na listę wpisało się ok. 950 tys. osób (ok. 54,5 proc. ogółu ludności, najczęściej w trzeciej grupie). B. Chrzanowski, A. GąSIORowski, K. Steyer, Polska podziemna..., s. 59.

${ }^{14}$ M. WARDZYŃSKa, Wysiedlenia ludności polskiej z okupowanych ziem polskich właczonych do III Rzeszy w latach 1939-1945, Warszawa 2017, s. 47.

${ }^{15}$ D. Matelski, Niemcy i mniejszość niemiecka..., s. 41-42.

16 Tamże, s. 41, 46-49.

${ }^{17}$ Relacje Niemców z Polakami układały się różnie. Zob. Wojna na Kaszubach..., s. 93 (wspólne zabawy, festyny, dożynki), 107 (mieszane małżeństwa), 114 (wybijanie szyb w oknach Polaków), 127 (witanie Wehrmachtu kwiatami przez mniejszość niemiecką).

18 Tamże, s. 52, 54-55.

${ }^{19}$ M. Innatowicz, Villa Musica. Dzieje gniazda rodziny Panków w zarysie, Wejherowo 2016, s. 14. 


\section{UWARUNKOWANIA WOJENNE}

Nienawiść do narodu polskiego znalazła wyraz w rozkazie Adolfa Hitlera z 22 sierpnia 1939 r., a następnie w wygłoszonym 1 września 1939 r. obwieszczeniu gauleitera Alberta Forstera przyłączającym Wolne Miasto Gdańsk do III Rzeszy. Anektowane ziemie Pomorza Gdańskiego nazwane zostały przez władze hitlerowskie Prowincją Rzeszy Gdańsk-Prusy Zachodnie i powiększone o byłe Wolne Miasto Gdańsk, niektóre powiaty Prus Wschodnich i skrawek województwa warszawskiego. Prowincja obejmowała powierzchnię ponad 26 tys. kilometrów kwadratowych, zamieszkaną przez $2,3 \mathrm{mln}$ osób ${ }^{20}$. Jak pisał Donald Steyer, „[o]kręg ten traktowany był [...] przez hitlerowców jako wzorcowy - Mustergau, a realizowana tutaj polityka eksterminacyjna okupanta stanowić miała w pewnym sensie wzór do naśladowania na innych terenach" ${ }^{21}$. W ramach szeroko zakrojonej akcji przeciwko polskiej inteligencji (Intelligenzaktion oraz Außerordentlische Befriedungsaktion - 'nadzwyczajnej akcji pacyfikacyjnej') rozpoczęto na Pomorzu Gdańskim operację eksterminacyjną pod kryptonimem „Tannenberg” (Unternehmen Tannenberg). Już 1 września 1939 r. aresztowano w Gdańsku osoby widniejące na liście proskrypcyjnej, m.in. przywódców gdańskiej Polonii (Antoniego Lendziona), księży (Bronisława Komorowskiego) i urzędników Komisariatu Generalnego RP. Maltretowano ich w budynku żeńskiej szkoły średniej Victoria Schule, a następnie większość przewieziono do KL Stutthof, gdzie część została zamordowana w lesie ${ }^{22}$. Drugą zakrojoną na dużą skalę akcję antypolską - Saüberungsaktion ('akcja oczyszczania') przeprowadzono w dniach 14-30 września. Spośród ok. 20 tys. aresztowanych mężczyzn w wieku od 14 do 70 lat wyselekcjonowano 2,5 tys. przeznaczonych na śmierć. Poszukiwano w szczególności osób z organizacji Grunwald, mających prowadzić antyniemiecką dywersję na tyłach wrześniowego frontu, oraz członków Społecznej Sieci Informacyjnej i Legionu Gdańskiego, rekrutujących się głównie spośród urzędników i kolejarzy z Wolnego Miasta Gdańska. Szybko zostali oni zdekonspirowani przez niemiecki wywiad, aresztowani już w pierwszym dniu wojny, a następnie straceni w KL Stutthof

20 J. DANILuK, SS w Gdańsku. Wybrane zagadnienia, Gdańsk 2013, s. 111; W. JASTRZĘBSKI, J. SzILING, Okupacja hitlerowska na Pomorzu Gdańskim w latach 1939-1945, Gdańsk 1979, s. 51.

${ }^{21}$ D. Steyer, Eksterminacja ludności polskiej na Pomorzu Gdańskim w latach 1939-1945, Gdynia 1967, s. 7. Hitlerowcom kazano „nie okazywać śladu miękkiej sentymentalności” oraz „odrzucić - jak mówił Hitler - śmieszny, niedorzeczny humanitaryzm”. Zob. też recenzję: W. ZAJEWsKi, Eksterminacja Polaków na Pomorzu Gdańskim, „Litery”, 6(1967), nr 6, s. 29.

22 S. Mikos, Gdańsk w okresie II wojny światowej, w: Historia Gdańska, t. 4, cz. 2: 1920-1945, red. E. Cieślak, Sopot 1999, s. 104-108, 110; Gdańsk 1939. Wspomnienia Polaków-Gdańszczan, oprac. B. Zwarra, Gdańsk 2002, s. 17, 30; D. STEYER, Eksterminacja ludności polskiej..., s. 134. 
i Piaśnicy ${ }^{23}$. W Berlinie, w odpowiedzi na domniemane bestialstwa Polaków dokonywane w tzw. krwawą niedzielę bydgoską, zapadła decyzja o powołaniu ochotniczych paramilitarnych grup Selbstschutzu składających się z członków niemieckiej mniejszości narodowej w Polsce, których zadaniem było m.in. przeprowadzanie samosądów i mordowanie polskich współobywateli. W ślad za jednostkami Wehrmachtu na teren Pomorza wkraczały formacje policyjne, w skład których wchodziły oddziały operacyjne - Einsatzkommando (EK). Za eksterminację Polaków (np. rozstrzelanie obrońców poczty gdańskiej) w poważnej mierze odpowiadało działające na obszarze Gdańska, Gdyni i Wejherowa EK-16 ${ }^{24}$. Wyroki śmierci zaczęły też wydawać cywilne sądy specjalne (Sondergericht) oraz cywilne sądy doraźne (Standgericht).

Na mocy wydanego 7 października 1939 r. dekretu Hitlera O umocnieniu niemczyzny władze okupacyjne podjęły konkretne decyzje o eksterminacji i deportacji ludności polskiej z terenów włączonych do III Rzeszy oraz sprowadzaniu na ich miejsce osadników niemieckich. Wyraźnie podkreślono zamiar unicestwienia przywódczych elit narodu polskiego, które według nazistów stanęłyby na drodze do realizacji planu stworzenia Lebensraumu. Nadzór nad depolonizacją regionu powierzono komisarzowi Rzeszy ds. umacniania niemczyzny Heinrichowi Himmlerowi ${ }^{25} .12$ października Niemcy rozpoczęli deportacje z Gdyni-Orłowa do Generalnego Gubernatorstwa. W pierwszej kolejności ofiarami represji padały: inteligencja, przedstawiciele Kościoła, rodziny osób zamordowanych na Pomorzu i ludność żydowska ${ }^{26}$. Specyficznie potraktowani zostali Kaszubi: część zamordowano, a pozostawionych przy życiu deportowano do Kartuz i Wejherowa albo do Generalnego Gubernatorstwa, w okolice Kielc. Osoby podlegające wysiedleniu zabierano z domów nad ranem, około trzeciej, piątej w nocy, dając im zaledwie pół godziny na zabranie trzydziestu kilogramów bagażu osobistego i niewielkiej ilości gotówki, z czego zresztą później ich ograbiano. Następnie przesiedleńców umieszczano po sto, dwieście osób w bydlęcych wagonach i w takich warunkach przez kilka dni wieziono na południe, często bez wody i jedzenia ${ }^{27}$. Część Polaków

${ }^{23}$ B. Zwarra, Wspomnienia gdańskiego bówki, t. 2, Gdańsk 1985, s. 7, 17-18, 21, 26; B. ChrZanowSki, A. Gąsiorowski, K. Steyer, Polska podziemna..., s. 23, 27, 32, 38-39, 47, 92, 94. Czy kryptonim „Tannenberg” był niemiecką odpowiedzią na polski „Grunwald”? Tamże, s. 71, przyp. 31.

${ }^{24}$ Tamże, s. 53-54.

${ }^{25}$ B. Chrzanowski, Wypędzenia z Pomorza, „Biuletyn IPN”, 5(2004), s. 34; Źródła do dziejów Polski w XIX i XX wieku, t. 4, cz. 1: Wybór tekstów źródłowych, oprac. J.R. Szaflik, R. Turkowski, Pułtusk 2000, s. 76-77, 84.

${ }^{26}$ B. Chrzanowski, Wypędzenia..., s. 42.

${ }^{27}$ M. Sтерко, Wybrane aspekty nazistowskiej polityki ludnościowej w okupowanej Gdyni w latach 1939-1940, w: Przemoc i dzień powszedni w okupowanej Polsce, red. T. Chinciński, Gdańsk 2011, s. 96-108; Wojna na Kaszubach..., s. 157, 163-164 (obóz w Wysinie). 
trafiła do obozów przejściowych, m.in. w Toruniu, Tczewie, Smukale, Potulicach i Wysinie. Warunki w czasie deportacji nie spełniały nawet podstawowych zasad humanitarnych, co prowadziło do olbrzymiej śmiertelności ${ }^{28}$. Na miejsce Polaków sprowadzono Niemców bałtyckich, a niektóre gospodarstwa rolne przejmowali miejscowi Niemcy.

Pierwsze miesiące hitlerowskiej polityki wobec podbitej ludności przyniosły masowe deportacje i egzekucje w 69 miejscach na terenie Pomorza Gdańskiego. Na przykład między 6 a 22 listopada 1939 r. w Kościerzynie wysiedlono 2 tys. osób, a 600 rozstrzelano, natomiast w Skarszewach wysiedlono 1000, a rozstrzelano $240^{29}$. W wysyłanych do Londynu raportach Komendy Głównej Związku Walki Zbrojnej nie pada jednak nazwa Piaśnica ${ }^{30}$.

\section{HITLEROWSKIE ZBRODNIE W PIAŚNICY I PAMIĘĆ}

Wieś Piaśnica leży na terenie Pojezierza Kaszubskiego, w Puszczy Darżlubskiej, około dziewięciu kilometrów na północ od Wejherowa. Miejsce kaźni nie było przypadkowe. Morderstw dokonywano w lesie, daleko od miejscowości i na trasie wiodącej z więzień i aresztów. Albert Forster nawoływał do zbrodni, przemawiając do tłumu Niemców zebranego w Wejherowie: „Musimy tych zawszonych Polaków wytępić, począwszy od kołyski. Możecie z nimi zrobić, co chcecie”. Tłum zaś krzyczał w odpowiedzi: „Niech zginą polskie psy! Śmierć Polakom!”31. Hitler z góry obdarzył morderców tajną amnestią już 4 września 1939 r. Co ciekawe, w memoriale gdańskiego Gestapo wystosowanym 21 października do Głównego Urzędu SS użyto jednoznacznego sformułowania fizyczna likwidacja ${ }^{32}$, choć $\mathrm{z}$ reguły naziści maskowali zbrodnie, posługując się ezopowym językiem i sformułowaniami w rodzaju: akcja, zabezpieczenie, oczyszczenie, ewakuacja, specjalne zadania, usuwanie. Aby skazać ludzi na śmierć, wystarczyło podkreślenie złych intencji, złej osobowości podejrzanych lub złośliwa denuncjacja lokalnych Niemców. Donosicielstwo nie było zresztą potępiane w niemieckim

${ }^{28}$ Tamże, s. 45-47. W późniejszym czasie obozy przeznaczono m.in. dla Polaków wysiedlonych z Zamojszczyzny. Żydów więziono w dzielnicach Gdańska: Oruni, Brzeźnie i Nowym Porcie.

${ }^{29}$ M. WARDZYŃsKa, Wysiedlenia ludności polskiej..., s. 42, 47, 49.

${ }^{30}$ Armia Krajowa w dokumentach 1939-1945, t. 1: Wrzesień 1939-czerwiec 1941, oprac. H. Czarnocka i in., Wrocław 1990, s. 105-106 (nastroje), 117-118 (deportacje), 119 (w meldunku „Grota” do Londynu z 8 II 1940 r. stwierdzono, że wobec Kaszubów „Niemcy zastosowali specjalne tolerancyjne metody").

${ }^{31}$ Przewodnik. Piaśnica. Miejsce niemieckich zbrodni na Pomorzu w 1939 roku, red. M. Tomkiewicz, Wejherowo 2017, s. 11-12.

${ }^{32}$ W. JASTRZĘBSKI, J. SzILING, Okupacja hitlerowska..., s. 90; Gdańsk 1939..., s. 377. 
społeczeństwie. „Każdy kto lekceważy ten obowiązek, nie może się uważać za przyzwoitego Niemca" - twierdzono w kręgach władzy. Zdrowe odczucia narodu (a więc nienawiść do Polaków) miały się objawić w postaci morderstw ${ }^{33}$. Największe ich nasilenie wystąpiło w październiku i listopadzie 1939 r., a wykonawcami zbrodniczych decyzji Hitlera stali się m.in. gauleiter Forster, burmistrz Pucka Friedrich Freimann, dyrektor kryminalny gdyńskiego Gestapo SS-Hauptsturmführer Friedrich Class oraz funkcjonariusze Einsatzkommando 16 pod dowództwem SS-Sturmbannführera dr. Rudolfa Trögera. Bezpośredni udział w masakrze wziął również wydzielony pododdział EK-16 Wachsturmbann SS „Eimann” pod dowództwem Obersturmbannführera Kurta Eimanna. Pomagali w niej także członkowie wejherowskiego Selbstschutzu, kierowani przez Hansa Söhna i Gustawa Bambergera ${ }^{34}$.

Ofiary wywlekano z domów i więzień, gdzie były wcześniej maltretowane ${ }^{35}$, i w samej bieliźnie ustawiano w grupach po pięć, sześć osób w pozycji stojącej lub klęczącej nad wykopanymi wcześniej przez niemieckich rolników dołami śmierci. Jedni zabijani byli strzałem w głowę lub w serce, a innym roztrzaskiwano czaszki kolbami karabinów. Ranni byli dobijani lub zasypywani żywcem, a małe dzieci roztrzaskiwane o drzewa. Szczególnie krwawym dniem okazał się - nieprzypadkowo - 11 listopada 1939 r., kiedy to w lasach Piaśnicy rozstrzelano 314 osób. Ofiarami byli działacze społeczni, oficerowie, prawnicy, nauczyciele, księża, lekarze, ziemianie, przemysłowcy, członkowie Polskiego Związku Zachodniego, powstańcy, urzędnicy, a także chłopi i robotnicy, których jedyną winą było przywiązanie do polskości. Największa hekatomba dotknęła mieszkańców Gdańska, Gdyni, Kartuz, Kościerzyny, Pucka, Redy, Rumi, Wejherowa i wielu pomorskich wsi. Egzekucje trwały do pierwszego kwartału 1940 r. Mimo grożącego karą śmierci zakazu wstępu do lasu miejscowa ludność, słysząc w oddali odgłosy strzałów, szybko dowiedziała się o masakrze. Po wojnie najważniejsi świadkowie złożyli zeznania w sprawie. Elżbieta Ellwart z Orla, która przypadkowo widziała w lesie szczegóły zbrodni, opisywała:

${ }^{33}$ R. Grunberger, Historia społeczna Trzeciej Rzeszy, przeł. W. Kalinowski, Warszawa 1987, s. 166, 184-186.

${ }^{34}$ Więzieniem i katownią dla Polaków były piwnice willi należącej przed wybuchem wojny do lekarza i znanego wejherowskiego społecznika dr. Franciszka Panka, zajętej następnie przez Gestapo. Budynek ten stał się również mieszkaniem Söhna, centrum dowodzenia i magazynem zrabowanych rzeczy. Dr Franciszek Panek (1858-1931). M. Innatowicz, Villa Musica ..., s. 5, 14.

${ }^{35}$ Wojna na Kaszubach..., s. 156 (zabójstwo uwięzionego w Wejherowie nauczyciela Kossa, po 20 XI 1939 r.). 
Rozejrzałam się wokół siebie i zobaczyłam świeżo rozkopany prostokątny dół, a w nim wielu zabitych. Rozpoznałam wśród nich mężczyzn i kobiety. Widziałam także zabitych leżących na ziemi obok dołu oraz kilkanaście osób czołgających się po ziemi. Byli to zapewne ciężko ranni. Uprzytomniłam sobie wówczas, że to stąd dochodziły do moich uszu jęki w chwili, gdy szłam przez las. [...] Mieszkańcy Orla - Józef Müller i Leon Myszka (obaj nie żyją) mówili mi, że byli również świadkami egzekucji w lasach piaśnickich [...]. Widzieli, jak skazańcy musieli ustawiać się rzędem nad wykopanym dołem, następnie rozstrzelani przez Niemców wpadali $\operatorname{tam}^{36}$.

Ellwart ocalała dzięki temu, że znała język niemiecki i używała panieńskiego nazwiska Lehmann. Drugi świadek, kolejarz-dróżnik Teofil Mudlaff, w dniach masakry naliczył podczas służby około pięciuset samochodów jadących z więźniami do Piaśnicy. Nawet niektórzy Niemcy, aluzyjnie lub bez ogródek, wspominali, co się dzieje. Miejsca zbrodni - 35 masowych grobów - zostały przezornie zamaskowane. W 1944 r. hitlerowcy kazali więźniom Stutthofu wykopać i spopielić większość zwłok. Akcji nadano kryptonim „1005”, a informację o liczbie usuwanych ciał nazwano meldunkami pogodowymi! Jak wykazała ekshumacja z 1946 r., jedynie dwie mogiły zawierały nienaruszone zwłoki łącznie 305 osób, a dwa inne doły śmierci od początku były puste i zasypane.

Barbarze Bojarskiej i Elżbiecie Grot udało się stworzyć listę tylko 800 rozpoznanych Polaków i 1200 więźniów z Niemiec. Przypuszczalna liczba 12 tys. ofiar nadal wymaga weryfikacji. Wśród zamordowanych Polaków znaleźli się: sędzia Sądu Okręgowego w Gdyni Władysław Kiedrowski, polski Tatar, prawnik i działacz BBWR Leon Najman Mirza-Kryczyński, nadleśniczy Roman Kuniewski, około pięćdziesięciu księży z diecezji chełmińskiej (ks. Bolesława Witkowskiego powieszono w szatach liturgicznych), ojcowie jezuici z Gdyni, dyrektor gimnazjum żeńskiego w Wejherowie s. Alicja Kotowska (beatyfikowana w 1999 r.), nauczycielki Stanisława i Kazimiera Pankówny, kompozytor Stanisław Bereza, wójt gminy Wejherowo-Wieś mjr Edward Łakomy, jego zastępca Bolesław Kralewski, burmistrz Wejherowa Teodor Bolduan, wójt Rumi Hipolit Roszczynialski, dyrektor Urzędu Morskiego w Gdyni Stanisław Łęgowski, inspektor szkolny Karol Kopeć, urzędnicy Komisariatu Rządu w Gdyni, redaktor „Gazety Gdańskiej” Władysław Cieszyński, działacze partii politycznych, stowarzyszeń i związków zawodowych, jeńcy wojskowi z Gdyni i Helu, obrońca Poczty Polskiej Leon Fuz oraz rodziny żydowskie. Analiza listy ofiar sporządzonej przez Bojarską i Grot pod kątem wykształcenia i wykonywanego zawodu pokazuje, że największe straty poniosła inteligencja ${ }^{37}$.

\footnotetext{
${ }^{36}$ B. Bojarska, Piaśnica ..., s. 49-50.

37 Tamże, s. 53; E. Grot, Zbrodnie hitlerowskie..., s. 38-39; D. STEYER, Eksterminacja ludności polskiej..., s. 67-69.
} 
Hitlerowcy mordowali też w Piaśnicy obywateli III Rzeszy. Od jesieni 1939 do wiosny 1940 r. co najmniej dwa razy w tygodniu ze składu pociągu relacji Szczecin-Gdańsk odczepiano dwa ostatnie wagony, a następnie kierowano je w stronę Lęborka i Wejherowa. Znajdowali się w nich niemieccy antynaziści, przedstawiciele mniejszości polskiej oraz Czesi. Ofiarami padli też przywiezieni z Niemiec pacjenci szpitali psychiatrycznych.

Pod wieloma względami porównywalne do zbrodni piaśnickiej były mordy dokonywane przez Niemców między 13 września a 8 grudnia 1939 r. w Lesie Szpęgawskim, położonym na północny wschód od Starogardu, w odludnym miejscu na trasie do Tczewa. Podobnie jak w Piaśnicy ofiarami Selbstschutzu i grupy SS „Eimann” padali przedstawiciele polskiej inteligencji, duchowieństwa, kombatanci, Żydzi i mordowani w ramach akcji T4 pacjenci szpitali psychiatrycznych (m.in. z Kocborowa, Świecia i Gniewu). Egzekucji dokonywano nad 33 przygotowanymi grobami, grzebiąc w nich od 5 do 7 tys. ludzi. W 1944 r. w celu zlikwidowania śladów zbrodni oprawcy nakazali wykopanie i spalenie zwłok, a więźniów, którzy się tym zajmowali, zamordowali jak w Piaśnicy ${ }^{38}$. Bydgoski Fordon, las Barbarka koło Torunia, Rudzki Most koło Tucholi, Mniszek i Igły pod Chojnicami, Karolewo i Radzim pod Sępólnem - to liczne miejsca hitlerowskich zbrodni ${ }^{39}$, w których zastosowano podobny jak pod Piaśnicą model działania, powielony m.in. w Palmirach czy podwileńskich Ponarach. Ludobójstwo trwało do 1945 r. Po wojnie Forstera skazano w Polsce na karę śmierci, ale inni sprawcy nie zawsze otrzymywali wyrok adekwatny do popełnionych czynów: Eimann skazany został przez amerykański sąd na cztery lata pozbawienia wolności (z których odbył dwa); Söhn mimo prowadzonego przez niemiecką prokuraturę dochodzenia nie stanął przed sądem; zaoczny wyrok na ukrywającego się Freimanna nigdy nie został wykonany, a Bamberger piastował urząd wiceburmistrza Hanoweru.

Według obliczeń historyków w latach 1939-1942 prześladowania na Pomorzu dotknęły 121-170 tys. osób z 14 miast i 163 wsi, a ok. 50 tys. zostało wygnanych z Gdyni. Poznanie pełnej prawdy historycznej o zbrodni w Piaśnicy wymaga według Elżbiety Grot dalszych kwerend archiwalnych w Niemczech, Polsce i Rosji, a także prac archeologicznych. Nie mniej ważne są też jednak działania na rzecz upamiętnienia miejsca i ofiar zbrodni ${ }^{40}$. Pierwsze kroki w tym kierunku podjęto po zakończeniu drugiej wojny światowej. Już w 1946 r. rozpoczęły się prace ekshumacyjne i uroczyste

\footnotetext{
${ }^{38}$ B. Bojarska, Piaśnica..., s. 38-67; Przewodnik. Piaśnica..., s. 4-8; M. WardzyńsKa, Byt rok 1939. Operacje niemieckiej policji bezpieczeństwa w Polsce. Intelligenzaktion, Warszawa 2009, s. 43, 67-69, 108, 148-152.

${ }^{39}$ D. STEYer, Eksterminacja ludności polskiej..., s. 68, 136-152; E. GROT, Zbrodnie hitlerowskie..., s. 29.

${ }^{40}$ Tamże, s. 42.
} 
pogrzeby. W 1955 r. lokalna społeczność ufundowała pamiątkowy monument i zadbała o godny wygląd grobów. Współcześnie archidiecezja gdańska z inicjatywy m.in. Stowarzyszenia „Rodzina Piaśnicka” ustanowiła sanktuarium maryjne z kaplicą-pomnikiem. Zadbano też o postawienie wielu indywidualnych i zbiorowych pomników nagrobnych, m.in. bł. s. Alicji Kotowskiej, Leona Mirzy-Kryczyńskiego i Romana Kuniewskiego, oraz krzyży, piety, figury Matki Bożej Swarzewskiej i pustej kołyski, która symbolizuje śmierć piaśnickich dzieci. Od 2015 r. w dawnej willi dr. Panka działa Muzeum Piaśnickie w Wejherowie - filia Muzeum Stutthof w Sztutowie ${ }^{41}$.

Istotną rolę w utrwalaniu pamięci narodowej pełnią różne formy edukacji i służące im pomocą rozmaite środki dydaktyczne: „Teki Edukacyjne IPN”, komiksy (Las piaśnicki Tomasza Meringa ${ }^{42}$ ), filmy fabularne (Kamerdyner Filipa Bajona ${ }^{43}$ ), a zwłaszcza filmy dokumentalne, m.in. Piaśnica. Golgota Pomorza w reżyserii Magdaleny Biernackiej i zrealizowana w serii „Młyny Historii” Piaśnica Mariusza Sławińskiego ${ }^{44}$. Nie zastąpią one jednak podstawowego źródła informacji, jakim jest uczniowski podręcznik, przygotowany w oparciu o ramowy program nauczania. Autor artykułu zgłasza więc jeszcze jeden postulat - wyraźnego zaznaczenia zbrodni w Piaśnicy w wykładzie podręcznikowym ${ }^{45}$.

Znaczenie miejsca pamięci narodowej w Piaśnicy jako elementu umacniania regionalnego i ogólnonarodowego patriotyzmu dobitnie wyraził ksiądz Franciszek Manthey (1904-1971) z Pelplina - filozof i religioznawca, człowiek pogranicza, syn Niemca i Polki:

Cmentarz w Piaśnicy stał się właśnie wtedy [w latach 1939-1940 - D.O.] pomnikiem Kaszub, symbolem odrzucenia tego wszystkiego, co miało związek z Niemcami i niemczyzną, a wiadomo, że zabici stanowią potężniejszą siłę niż żyjący ${ }^{46}$.

${ }^{41}$ Przewodnik. Piaśnica..., passim.

${ }^{42}$ T. Mering, Las piaśnicki. Fabularyzowany komiks historyczny, Sztutowo-Wejherowo 2016.

${ }^{43}$ Kamerdyner, reż. F. Bajon, 2018.

${ }^{44}$ Golgota Pomorza, reż. M. Biernacka, 2017; Piaśnica, reż. M. Sławiński, 2018. Edukacyjną rolę pełnią również sceny rekonstrukcyjne, które dzięki scenografii i rekwizytom pozwalają autorowi artykułu zrozumieć atmosferę okupacji, jak 19 VIII 2018 r. na planie filmu Młyny historii w Wejherowie. O edukacyjnej roli muzeów i komiksów zob. np. „Pamięć.pl. Biuletyn IPN”, 3(2012), a filmów i gier planszowych - np. „Pamięć.pl. Biuletyn IPN”, 9(2013). 5 X 2019 r. w Muzeum II Wojny Światowej w Gdańsku odbył się koncert „Moja Piaśnica” w reżyserii Mariusza Sławińskiego. Zaprezentowano wówczas utwory Mirosława Odynieckiego z muzyką Szymona Kamińskiego i zespołu 4 Razy w Roku. Relację Bożeny Olechnowicz w „Panoramie” TVP3 Gdańsk zob. Panorama 05.10.2019 18:30, „TVP3 Gdańsk” [online], 5 X 2019 [dostęp: 10 X 2019], dostępny w internecie: <https:// gdansk.tvp.pl/44707528/05102019-183>.

${ }^{45}$ W podręcznikach do liceów z lat 2003-2018 (np. wydawnictw Operon, Nowa Era czy WSiP) Piaśnica najczęściej zaznaczana jest tylko na mapkach, a prawie wcale nie ma jej w tekście wykładu.

${ }^{46}$ F. Manthey, O historii Kaszubów, Gdańsk 1997, s. 56. 


\section{BIBLIOGRAFIA}

\section{ŹRÓDŁA PUBLIKOWANE}

Aneksy, oprac. B. Bojarska, E. Grot, w: B. Bojarska, Piaśnica. Miejsce martyrologii i pamięci. Z badań nad zbrodniami hitlerowskimi na Pomorzu, Wejherowo-Gdańsk 2009.

Armia Krajowa w dokumentach 1939-1945, t. 1: Wrzesień 1939-czerwiec 1941, oprac. H. Czarnocka i in., Wrocław 1990.

Gdańsk 1939. Wspomnienia Polaków-Gdańszczan, oprac. B. Zwarra, Gdańsk 2002.

Relacje ofiar i świadków eksterminacyjnej polityki okupanta, w: D. Steyer, Eksterminacja ludności polskiej na Pomorzu Gdańskim w latach 1939-1945, Gdynia 1967.

Wojna na Kaszubach. Pamięć polskich i niemieckich świadków, oprac. K. Madoń-Mitzner, R. Borchers, Gdańsk 2014.

Zwarra B., Wspomnienia gdańskiego bówki, t. 2, Gdańsk 1985.

Źródta do dziejów Polski w XIX i XX wieku. Lata 1939-1945, t. 4, cz. 1: Wybór tekstów źródtowych, oprac. J.R. Szaflik, R. Turkowski, Pułtusk 2000.

\section{LITERATURA}

Bojarska B., Piaśnica. Miejsce martyrologii i pamięci. Z badań nad zbrodniami hitlerowskimi na Pomorzu, Wejherowo-Gdańsk 2009.

Borzyszkowski J., Gdańsk i Pomorze w XIX i XX wieku, Wydawnictwo Uniwersytetu Gdańskiego, Gdańsk 1999.

Breza B., Pomiędzy oporem a przystosowaniem. Kaszubi w Okręgu Rzeszy Gdańsk-Prusy Zachodnie 1939-1945, „Rocznik Gdański”, 64(2004), z. 1-2, s. 49-60.

Chrzanowski B., Wypędzenia z Pomorza, „Biuletyn IPN”, 5(2004), s. 34-48.

Chrzanowski B., Gąsiorowski A., Steyer K., Polska podziemna na Pomorzu w latach 1939-1945, Gdańsk 2005.

Daniluk J., SS w Gdańsku. Wybrane zagadnienia, Gdańsk 2013.

Drzycimski A., Polacy w Wolnym Mieście Gdańsku w latach 1920-1933, Wrocław 1978.

Groт E., Zbrodnie hitlerowskie w Piaśnicy: stan badań i postulaty, „Acta Cassubiana”, 3(2001), s. 27-42.

Grunberger R., Historia społeczna Trzeciej Rzeszy, t. 1, przeł. W. Kalinowski, Warszawa 1987.

Historia Gdańska, t. 4, cz. 2: 1920-1945, red. E. Cieślak, Sopot 1999.

Innatowicz M., Villa Musica. Dzieje gniazda rodziny Panków w zarysie, Wejherowo 2016.

JASTRZĘBSKi W., SZILING J., Okupacja hitlerowska na Pomorzu Gdańskim w latach 1939-1945, Gdańsk 1979.

Manthey F., O historii Kaszubów, Gdańsk 1997.

Matelski D., Niemcy i mniejszość niemiecka na Pomorzu Gdańskim (1920-1945), „Rocznik Gdański”, 58(1998), z. 1, s. 39-59.

Mering T., Las piaśnicki. Fabularyzowany komiks historyczny, Sztutowo-Wejherowo 2016.

Mıкos S., Gdańsk w okresie II wojny światowej, w: Historia Gdańska, t. 4, cz. 2: 1920-1945, red. E. Cieślak, Sopot 1999. 
Panorama 05.10.2019 18:30, „TVP3 Gdańsk” [online], 5 X 2019 [dostęp: 10 X 2019], dostępny w internecie: <https://gdansk.tvp.pl/44707528/05102019-183>.

Przemoc i dzień powszedni w okupowanej Polsce, red. T. Chinciński, Gdańsk 2011.

Przewodnik. Piaśnica. Miejsce niemieckich zbrodni na Pomorzu w 1939 roku, red. M. Tomkiewicz, Wejherowo 2017.

StaŻEWSKi M., Sprawa „niebezpieczeństwa polskiego” na łamach niemieckiej prasy w Gdańsku w pierwszej połowie 1919 roku, w: Gdańsk i Pomorze w XX wieku, red. M. Andrzejewski, Gdańsk 1997.

STEPKо M., Wybrane aspekty nazistowskiej polityki ludnościowej w okupowanej Gdyni w latach 19391940, w: Przemoc i dzień powszedni w okupowanej Polsce, red. T. Chinciński, Gdańsk 2011.

Steyer D., Eksterminacja ludności polskiej na Pomorzu Gdańskim w latach 1939-1945, Gdynia 1967. Szyмiкowski D., „Zrzesz Kaszëbskô” w latach 1933-1939, Bolszewo 2010.

WaPIŃski R., Polska i małe ojczyzny Polaków. Z dziejów ksztaltowania się świadomości narodowej w XIX i XX wieku po wybuch II wojny światowej, Wrocław 1994.

WAPIŃSKI R., Świadomość polityczna w Drugiej Rzeczypospolitej, Łódź 1989.

WARDZYŃSKa M., Byt rok 1939. Operacje niemieckiej policji bezpieczeństwa w Polsce. Intelligenzaktion, Warszawa 2009.

WARDZYŃSKa M., Wysiedlenia ludności polskiej z okupowanych ziem polskich włączonych do III Rzeszy w latach 1939-1945, Warszawa 2017.

Zajewski W., Eksterminacja Polaków na Pomorzu Gdańskim, „Litery”, 6(1967), nr 6, s. 29.

Zajewski W., Wolne Miasto Gdańsk, „Litery”, 9(1970), nr 6, s. 30-31.

\title{
THE NAZI-GERMAN CRIMES IN POMERANIA-GDAŃSK IN THE YEARS 1939-1940. PIAŚNICA. GENESIS - CONDITIONS - COURSE AND MEMORY
}

\begin{abstract}
The crime of the German-Nazi invader carried out in Piaśnica was the largest in northern Poland and the occupied country from autumn 1939 to spring 1940. About 12,000 people from the Polish political elite and intellectuals, especially from representatives of clergy of the Roman Catholic Church were killed, among patients in psychiatric hospitals. Genesis of his crime is a German revanchism against the Versailles dictat, postulates of Lebensraum (germ. 'living space'), germanization and the criminal ideology of Nazism. The squad Selbstschutz (paramilitary units the German minority in Poland) and SS - operational group Wachsturmbann "Eimann" and Einsatzkommando 16 are responsible for this genocide and ethnic cleansing planned before the war, including deportation of Poles to General Government and KL Stutthof. In a difficult situation, the regional Kashubians (Pomerania ethnic minority), have to choose between adaptation and extermination. Piaśnica for the German-Nazis was to serve as a model for further crimes, for example in the Szpęgawsk. Nowadays on the initiative of Piaśnica Family Association the Piaśnica forest is a place of national remembrance with the sanctuary of the Blessed Virgin Mary.
\end{abstract}

Keywords: Piaśnica, Selbstschutz, SS-Wachsturmbann “Eimann”, exterminations. 